\title{
RISK FACTORS OF BREAST CANCER IN WOMEN: A NEW EVIDENCE FROM SURAKARTA, CENTRAL JAVA, INDONESIA
}

\author{
Yana Listyawardhani'), Ambar Mudigdo²), Rita Benya Adriani3) \\ 1)Masters Program in Public Health, Universitas Sebelas Maret \\ ${ }^{2)}$ Department of Anatomic Pathology, Faculty of Medicine, Universitas Sebelas Maret \\ 3)Diploma Programin Speech Therapy, School of Health Politechnics Surakarta
}

\begin{abstract}
Background: Breast cancer is a leading type of cancer affecting women in developed and developing countries. Breast cancer is the leading cause of death among women in Indonesia with 19,731 cases of death in 2014. In addition to mortality, breast cancer causes psychosocial effect in the affected and the family. Studies have shown that the risk factors for developing breast cancer include being female, obesity, lack of physical exercise, drinking alcohol, hormone replacement therapy during menopause, ionizing radiation, early age at first menstruation, having children late or not at all, older age, and family history. This study aimed to determine the risk factors of breast cancer in women at Dr. Moewardi Hospital, Surakarta, Central Java.

Subjects and Method: This was a case control study conducted at Dr. Moewardi Hospital, Surakarta, from October to December 2017. A total sample of 200 study subjects consisting of 100 women with breast cancer and 100 women without breast cancer were selected for this study by fixed disease sampling. The dependent variable was breast cancer. The independent variables were age at menarche, age at first pregnancy, parity, duration of breastfeeding, use of fertility hormone, duration of hormonal contraceptive use, and age at menopause. The data was collected by questionnaire and analyzed by a multiple logistic regression.

Results: The risk of breast cancer increased with earlier age at menarche $<12$ years old $(\mathrm{OR}=2.71 ; 95 \% \mathrm{CI}=1.06$ to $6.96 ; \mathrm{p}=0.037)$, delayed age at first pregnancy $\geq 30$ years old $(\mathrm{OR}=3.01 ; 95 \% \mathrm{CI}=1.16$ to $7.78 ; \mathrm{p}=0.023)$, delayed age at menopause $\geq 55$ years old $(\mathrm{OR}=1.07 ; 95 \% \mathrm{CI}=0.82$ to $6.30 ; \mathrm{p}=0.001)$, longer hormonal contraceptive use $\geq 10$ years $(\mathrm{OR}=3.25 ; 95 \% \mathrm{CI}=1.20$ to $9.63 ; \mathrm{p}=$ 0.003).

Conclusion: The risk of breast cancer increases with earlier age at menarche, delayed age at first pregnancy, delayed age at menopause, longer hormonal contraceptive use.
\end{abstract}

Keywords: breast cancer, risk factor

\section{Correspondence:}

Yana Listyawardhani. Masters Program in Public Health, Universitas Sebelas Maret, Jl. Ir. Sutami 36 A, Surakarta 57126, Central Java.

Email: yanalistya@gmail.com. 